Agrisaintifika

Jurnal Ilmu-Ilmu Pertanian

Vol. 2, No. 1, 2018

\title{
Analisis Pengaruh Agrowisata Terhadap Peningkatan Pendapatan Petani Bunga Krisan Di Kecamatan Bandungan Kabupaten Semarang
}

\author{
Umi Lestariningsih, Agus Setiadi dan Hery Setiyawan \\ Program Studi S1 Agribisnis, Fakultas Peternakan dan Pertanian, \\ Universitas Diponegoro, Tembalang, Semarang 50275 - Indonesia \\ Email: umilestariningsihfpp@gmail.com
}

\begin{abstract}
ABSTRAK
Tujuan penelitian ini untuk menganalisis perbedaan pendapatan petani bunga krisan sebelum dan sesudah adanya agrowisata, serta menganalisis pengaruh agrowisata terhadap peningkatan pendapatan petani bunga krisan di Kecamatan Bandungan Kabupaten Semarang. Metode yang digunakan dalam penelitian adalah metode survei. Lokasi penelitian dipilih secara purposive di Agrowisata Kampung Krisan Clapar Bandungan. Responden ditentukan secara purposive, yaitu anggota Kelompok Tani Gemah Ripah yang menanam bunga krisan yang berjumlah 32 orang. Penelitian telah dilaksanakan pada bulan November - Desember 2017. Pengumpulan data dilakukan dengan wawancara yang dibantu menggunakan kuesioner. Alat analisis yang digunakan adalah Paired Sample T-test dan regresi linier berganda. Hasil penelitian menunjukkan bahwa terdapat perbedaan pendapatan petani bunga krisan sebelum dan sesudah adanya agrowisata. Pendapatan petani setelah adanya agrowisata lebih tinggi dibanding pendapatan petani sebelum adanya agrowisata. Rata-rata pendapatan petani setelah adanya agrowisata sebesar Rp 31.713.636/tahun lebih tinggi dibanding pendapatan petani sebelum adanya agrowisata sebesar Rp 30.395.843/tahun. Agrowisata berpengaruh terhadap peningkatan pendapatan petani bunga krisan di Kecamatan Bandungan Kabupaten Semarang.
\end{abstract}

Kata Kunci : agrowisata, bunga krisan, pendapatan petani.

\section{Analysis Effect of Chrysanthemum Agrotourism to the Increasing of Chrysanthemum Farmers Income in Bandungan, Semarang Regency}

\begin{abstract}
The aims of this study are to analyze the difference of chrysanthemum farmers income before and after agrotourism and to analyze the effect of agrotourism on increasing of chrysanthemum farmers income in Bandungan, Semarang Regency. The method was to use survey method. The location of this study was in Kampung Krisan Clapar Bandungan Agrotourism that chosen by a purposive method. Respondents were determined by purposive sampling, that is members of Gemah Ripah Farmer Group who planted chrysanthemum flower totaling 32 respondents. This study was done in November - December 2017. Data were collected by interview using questionnaires. The analysis method was used Paired Sample T-test and Multiple Linear Regression. The results showed that there was a difference of chrysanthemum farmers income before and after agrotourism. Farmers income after agrotourism is higher than farmers income before agrotourism. The average of farmers income after agrotourism is $R p$ 31.713.636/year, higher than average farmers income before agrotourism Rp 30.395.843/year. Agrotourism affected the increasing of chrysanthemum farmers income in Bandungan, Semarang Regency.
\end{abstract}

Keywords: Agrotourism, Chrysanthemum, Farmers income.

\section{PENDAHULUAN}

Sektor pariwisata termasuk salah satu sektor perekonomian yang sangat potensial untuk dikembangkan di Indonesia. Sektor pariwisata mampu memberikan kontribusi yang baik bagi perekonomian negara. Data dari Kementrian Pariwisata menyebutkan bahwa antara tahun 2010 sampai tahun 2015 kontribusi pendapatan dari sektor pariwisata selalu mengalami peningkatan, selain itu kontribusi terhadap devisa negara pada tahun 2016 mencapai 184 triliun rupiah. Pariwisata juga mampu menyerap banyak tenaga kerja. Tahun 2016, sektor pariwisata mampu 
Agrisaintifika

Jurnal Ilmu-Ilmu Pertanian

Vol. 2, No. 1, 2018

Lestariningsih, et al. 2018

menyerap tenaga kerja sebanyak 12 juta jiwa atau $10,6 \%$ dari total keseluruhan tenaga kerja di Indonesia (Kementrian Pariwisata, 2016).

Pertanian di Indonesia memiliki potensi yang sama besarnya dengan sektor pariwisata untuk dikembangkan, mengingat sebagian besar sumber pendapatan masyarakat Indonesia bersumber dari pertanian. Indonesia juga dikenal sebagai negara agraris, dengan begitu banyak sumber daya alam yang jika diolah secara benar mampu meningkatkan kesejahteraan penduduknya. Oleh karena itu, dengan semakin banyak dan berkembangnya agrowisata juga akan berdampak pada peningkatan kesejahteraan petani yang terlibat dalam kegiatan tersebut.

Di Kabupaten Semarang, khususnya di Kecamatan Bandungan, yang terkenal dengan produksi bunga krisan, mulai mengembangkan potensi ini menjadi sebuah wisata baru, yakni agrowisata bunga krisan. Agrowisata bunga krisan ini tidak hanya menyuguhkan indahnya pemandangan bunga krisan tetapi juga edukasi tentang penanaman hingga pemanenan krisan. Pengembangan kawasan agrowisata bunga krisan di Kecamatan Bandungan ini tentunya akan berdampak pada kegiatan perekonomian masyarakat disekitarnya, khususnya bagi petani krisan yang usahanya dilibatkan dalam kegiatan agrowisata. Tujuan dari penelitian ini yaitu:

1. Menganalisis perbedaan pendapatan petani bunga krisan sebelum dan sesudah adanya agrowisata.

2. Menganalisis pengaruh agrowisata terhadap peningkatan pendapatan petani bunga krisan di Kecamatan Bandungan Kabupaten Semarang.

\section{METODE PENELITIAN}

\section{Waktu dan Lokasi Penelitian}

Penelitian ini telah dilaksanakan pada bulan November-Desember 2017 di kawasan Agrowisata Kampung Krisan Clapar Bandungan yang terletak di Dusun Clapar,
Desa Duren, Kecamatan Bandungan Kabupaten Semarang.

\section{Metode Penentuan Lokasi}

Lokasi yang dipilih dalam penelitian ini adalah kawasan Agrowisata Kampung Krisan Clapar Bandungan dengan pertimbangan bahwa kawasan tersebut merupakan agrowisata bunga krisan yang dikelola secara berkelompok yaitu oleh Kelompok Tani Gemah Ripah serta memiliki struktur kepengurusan dan keanggotaan yang baik.

\section{Metode Penelitian}

Metode yang digunakan dalam penelitian ini adalah metode survei. Metode survei merupakan pengumpulan data (informasi) dengan cara mengajukan pertanyaanpertanyaan kepada responden dengan menggunakan bantuan kuesioner (Dantes, 2012). Penentuan sampel dilakukan dengan metode purposive sampling yaitu teknik penentuan sampel dengan kriteria tertentu. Responden dalam penelitian ini adalah anggota Kelompok Tani Gemah Ripah yang berada di Kawasan Agrowisata Kampung Krisan Clapar Bandungan dan menanam bunga krisan sebagai komoditas utama usahataninya, sehingga responden dalam penelitian ini berjumlah sebanyak 32 orang.

\section{Metode Pengumpulan Data}

Pengumpulan data dilakukan dengan cara wawancara yang dibantu menggunakan kuesioner.Wawancara dilakukan pada anggota Kelompok Tani Gemah Ripah di Kawasan Agrowisata Kampung Krisan Clapar Bandungan.

Data yang diambil dalam penelitian ini adalah data primer dan data sekunder. Data primer diperoleh dari wawancara secara langsung pada responden, sedangkan data sekunder diperoleh dari instansi terkait.

\section{Metode Analisis Data}

Data yang telah diperoleh kemudian dianalisis menggunakan uji Paired Sample $T$ test dan uji regresi linier berganda dengan bantuan aplikasi SPSS versi 16.0 , sebelum data diuji menggunakan uji Paired Sample T- 
Agrisaintifika

Jurnal Ilmu-Ilmu Pertanian

Vol. 2, No. 1, 2018

Lestariningsih, et al. 2018

test dan uji regresi linier berganda, data terlebih dulu diuji menggunakan uji normalitas.

\section{Uji Normalitas Data}

Uji normalitas data digunakan untuk mengetahui apakah suatu data berdistribusi normal atau tidak. Data dikatakan berdistribusi normal apabila nilai signifikansinya $\geq 0,05$ dan tidak berdistribusi normal jika nilai signifikansinya $<0,05$ (Santoso, 2010).

\section{Uji Paired Sample T-test}

Uji Paired Sample T-test digunakan untuk mengetahui perbedaan pendapatan petani sebelum dan sesudah adanya agrowisata. Uji Paired Sample T-test bertujuan untuk mengetahui perbedaan antara dua data dari sampel yang sama (Santoso, 2010). Hipotesis yang digunakan adalah:

a. $\mathrm{H}_{0}: \mu \pi 1-\mu \pi 2=0$, yang artinya tidak terdapat perbedaan pendapatan petani bunga krisan sebelum dan sesudah adanya agrowisata.

b. $H_{a}: \mu \pi 1-\mu \pi 2 \neq 0$, yang artinya terdapat perbedaan pendapatan petani bunga krisan sebelum dan sesudah adanya agrowisata.

Kesimpulan dari uji Paired Sample T-test didapat dari signifikansinya, jika nilainya signifikan $(<0,05)$ maka $\mathrm{H}_{0}$ ditolak dan $\mathrm{H}_{\mathrm{a}}$ diterima dan sebaliknya (Yusri, 2016).

Uji Asumsi Klasik

Analisis regresi linier berganda harus memenuhi uji asumsi klasik yaitu:

Uji Multikolinearitas. Uji multikolinearitas bertujuan untuk mengetahui ada atau tidak hubungan korelasi yang kuat antar variabel independen (Ghozali, 2007). Multikolinearitas dapat diidentifikasikan melalui nilai $\mathrm{R}^{2}$ yang sangat tinggi (mendekati 1,00 atau 100\%) maka hal tersebut menandakan adanya multikolinearitas, nilai tolerance $\geq 0,1$ dan nilai VIF $\leq 10,000$ maka dapat disimpulkan bahwa antar variabel independen tidak terjadi multikolinearitas begitu pula sebaliknya (Prasetyo, 2013).

Uji Heteroskedastisitas. Model regresi yang baik tidak terjadi heteroskedastisitas. Heteroskedastisitas dapat terlihat dari scatter

diagram yang terbentuk, jika titik-titik pada scatter diagram membentuk pola tertentu dan teratur, maka data mengalami heteroskedastisitas, sedangkan jika tititk-titik pada scatter plot tersebar secara merata, maka dapat disimpulkan bahwa data tersebut homoskedastisitas (Prasetyo, 2013).

Uji Autokorelasi. Uji autokorelasi bertujuan untuk menguji apakah dalam sebuah model regresi linier ada korelasi antara kesalahan pengganggu pada periode 1 dengan kesalahan pada periode $\mathrm{t}-1$ (sebelumnya) (Zulfikar, 2016).

Analisis regresi linier berganda digunakan untuk mengetahui seberapa besar pengaruh agrowisata yang dinyatakan oleh jumlah pengunjung agrowisata yang membeli bunga, jumlah bunga krisan yang dibeli oleh pengunjung, luas lahan serta jumlah tenaga kerja sebagai variabel independen terhadap pendapatan petani bunga krisan (variabel dependen) di Kecamatan Bandungan Kabupaten Semarang. Hipotesis yang digunakan adalah:

a. $\mathrm{H}_{0}: \beta i k=0$, yang artinya adanya agrowisata tidak berpengaruh terhadap peningkatan pendapatan petani bunga krisan di Kecamatan Bandungan Kabupaten Semarang.

b. $H_{a}: \beta i k \neq 0$, yang artinya adanya agrowisata berpengaruh terhadap peningkatan pendapatan petani bunga krisan di Kecamatan Bandungan Kabupaten Semarang.

Persamaan regresi dalam penelitian ini adalah:

$$
Y=a+b_{1} X_{1}+b_{2} X_{2}+b_{3} X_{3}+b_{4} X_{4}+e
$$

Keterangan :

$$
\begin{aligned}
& \text { Y : Pendapatan petani } \\
& \text { setelah adanya } \\
& \text { agrowisata (Rp/tahun) } \\
& b_{1}, b_{2}, \quad \text { : Koefisien regresi } \\
& b_{3}, b_{4} \\
& \mathrm{X}_{1} \quad \text { : Jumlah pengunjung yang } \\
& \text { membeli bunga } \\
& \text { (orang/tahun) } \\
& \mathrm{X}_{2} \quad \text { : Jumlah bunga yang } \\
& \text { dibeli pengunjung }
\end{aligned}
$$


Agrisaintifika

Jurnal Ilmu-Ilmu Pertanian

Vol. 2, No. 1, 2018

Lestariningsih, et al. 2018

$\begin{array}{lll} & & \text { (batang/tahun) } \\ \mathrm{X}_{3} & : & \text { Luas lahan }\left(\mathrm{m}^{2}\right) \\ \mathrm{X}_{4} & : & \text { Jumlah tenaga kerja (HOK) } \\ \mathrm{E} & : & \text { Koefisien eror }\end{array}$

3. HASIL DAN PEMBAHASAN

Biaya Produksi, $\begin{aligned} & \text { Penerimaan dan } \\ & \text { Pendapatan Petani Sebelum Adanya } \\ & \text { Agrowisata }\end{aligned}$

Sebelum adanya Agrowisata kampung Krian Clapar, rata-rata total biaya produksi yang harus dikeluarkan oleh petani dalam menjalankan uahataninya dalam jangka waktu satu tahun (2 kali musim tanam) adalah sebesar Rp 61.244.781 yang terdiri atas biaya tetap dan biaya variabel. Rata-rata penerimaan yang diperoleh sebesar Rp 91.640.625 dengan pendapatan sebesar $\mathrm{Rp}$ 30.395.843, yang berasal dari penjualan bunga krisan secara langsung ke pasar maupun pendekor. Penerimaan yang didapatkan oleh petani tergantung pada jumlah produksi serta harga jual produk. Hal tersebut sesuai dengan pendapatan Ekowati et al. (2016) yang menyatakan bahwa penerimaan merupakan hasil kali antara jumlah produksi dengan harga jual. Pendapatan rata-rata petani merupakan selisih antara penerimaan dan biaya produksi. Menurut Sukirno (2000) menyatakan bahwa pendapatan merupakan hasil dari pendapatan dikurangi total biaya produksi.

\section{Biaya Produksi, Penerimaan dan Pendapatan Petani Sesudah Adanya Agrowisata}

Rata-rata biaya produksi yang harus dikeluarkan petani untuk menjalan usahataninya sesudah adanya agrowisata adalah sebesar Rp 61.244.781, tidak berbeda dengan biaya sebelum adanya agrowisata. Hal tersebut disebabkan karena tidak ada biaya tambahan yang harus dikeluarkan petani dalam kegiatan operasional agrowisata. Biaya produksi yang dikeluarkan petani dalam bertanam krisan terdiri atas biaya tetap dan biaya variabel. Menurut Blocher (2007) biaya produksi atau biaya total merupakan biaya yang mencakup komponen biaya tetap maupun biaya variabel.

Sesudah adanya agrowisata rata-rata penerimaan petani sebesar $\mathrm{Rp} 92.958 .437$ dengan rata-rata pendapatan sebesar $\mathrm{Rp}$ 31.713.636. Penerimaan maupun pendapatan petani sesudah adanya agrowisata lebih tinggi dibanding sebelum adanya agrowisata. Hal tersebut terjadi karena sesudah adanya agrowisata sumber pendapatan petani bertambah, bukan hanya dari hasil usahatani bunga krisan yang dijalankan melainkan juga dari kegiatan agrowisata, yang berupa pembagian hasil penjualan tiket dan penjualan bunga secara langsung kepada pengunjung agrowisata. Hal tersebut sesuai dengan pendapat Ekowati et al. (2014) yang menyatakan bahwa pendapatan petani dapat bersumber dari dalam maupun dari luar usahatani yang dijalankan.

Jumlah total pengunjung yang telah mengunjungi Agrowisata Kampung Krisan Clapar periode November 2016 sampai dengan Desember 2017 sebanyak 15.500 pengunjung. Jumlah pengunjung terbanyak biasanya terjadi pada akhir pekan dan hari libur nasional. Agrowisata kampung krisan ini sedikit banyak telah memberikan dampak positif, baik bagi dusun, kelompok tani serta petani yang kebunnya dibuka sebagai lahan wisata, khususnya dari segi finansial. Total penerimaan dari tiket agrowisata hingga Desember 2017 sebesar Rp 155.000.000, yang kemudian dibagikan untuk kas dusun sebesar Rp 15.500.000, kas kelompok tani Rp 15.500 .000 , petani yang dibuka kebunnya sebagai tempat agrowisata Rp 31.000 .000 (Rp 968.750 per petani), serta sisanya untuk keperluan operasional agrowisata.

\section{Uji Normalitas Data}

Hasil uji normalitas data dengan aplikasi SPSS versi 16.0 menggunakan uji One Sample Kolmogorov Smirnov dapat dilihat pada Tabel 1. 
Agrisaintifika

Jurnal Ilmu-Ilmu Pertanian

Vol. 2, No. 1, 2018

Lestariningsih, et al. 2018

Tabel 1. Hasil Uji Normalitas Data

\begin{tabular}{cll}
\hline \hline No & \multicolumn{1}{c}{ Variabel } & $\begin{array}{l}\text { Asymp. Sig } \\
\text { (2-tailed) }\end{array}$ \\
\hline 1 & $\begin{array}{l}\text { Pendapatan Sebelum } \\
\text { adanya Agrowisata }\end{array}$ & 0,719 \\
2 & $\begin{array}{l}\text { Pendapatan Sesudah } \\
\text { adanya Agrowisata }\end{array}$ & 0,708 \\
3 & $\begin{array}{l}\text { Jumlah Pengunjung } \\
\text { yang Membeli Bunga }\end{array}$ & 0,779 \\
4 & $\begin{array}{l}\text { Jumlah Bunga yang } \\
\text { Dibeli Pengunjung }\end{array}$ & 0,442 \\
5 & $\begin{array}{l}\text { Luas Lahan } \\
\text { Jumlah Tenaga Kerja }\end{array}$ & 0,168 \\
6
\end{tabular}

Berdasarkan Tabel 1. dapat diketahui bahwa keseluruhan variabel berdistribusi normal karena memiliki nilai signifikansi $\geq$ 0,05 . Hal tersebut sesuai dengan pendapat Santoso (2010) yang menyatakan bahwa uji normalitas data digunakan untuk mengetahui apakah suatu data berdistribusi normal atau tidak. Data dikatakan berdistribusi normal apabila nilai signifikansinya $\geq 0,05$ dan tidak berdistribusi normal jika nilai signifikansinya < 0,05 .

\section{Uji Paired Sample T-test}

Berdasarkan uji Paired Sample T-test menggunakan aplikasi SPSS versi 16.0 dapat diketahui bahwa nilai Sig. 2 tailed uji perbedaan pendapatan petani sebelum adanya agrowisata dengan pendapatan petani sesudah adanya agrowisata sebesar $0,000(<0,05), H_{0}$ ditolak dan $H_{a}$ diterima, sehingga dapat disimpulkan bahwa terdapat perbedaan pendapatan petani bunga krisan sebelum dan sesudah adanya agrowisata. Perbedaan pendapatan tersebut dapat timbul karena setelah adanya agrowisata, sumber pendapatan petani juga bertambah, bukan hanya berasal dari hasil penjualan bunga ke pasar saja, melainkan juga dari hasil pembagian uang tiket serta penjualan bunga secara langsung kepada pengunjung agrowisata.

Pengembangan kebun krisan petani menjadi kawasan agrowisata di Dusun Clapar telah memberikan dampak positif bagi lingkungan dan masyarakat, bukan hanya

petani yang telibat secara langsung yang merasakan manfaatnya, namun juga bagi perkembangan kawasan disekitarnya. Hasil penjualan tiket yang masuk ke kas dusun dimanfaakan untuk kepentingan bersama, seperti perbaikan jalan maupun pembangunan sarana prasarana umum. Hal ini tentunya akan semakin mendukung terciptanya kesejahteraan masyarakat. Allifah (2014) menyatakan bahwa pengembangan agrowisata akan berdampak bagi lingkungan dan masyarakat sekitarnya. Agrowisata akan meningkatkan kesadaran masyarakat terhadap pelestarian lingkungan, meningkatkan pendapatan petani, serta menciptakan lapangan pekerjaan, sehingga tingkat urbanisasi dan pengangguran dapat berkurang.

\section{Faktor-faktor \\ Berpengaruh Pendapatan Petani \\ Agrowisata terhadap Peningkatan}

Faktor agrowisata yang diambil sebagai parameter yang diduga berpengaruh terhadap peningkatan pendapatan petani dalam penelitian ini yaitu, jumlah pengunjung agrowisata yang membeli bunga krisan (orang/tahun), jumlah bunga krisan yang dibeli oleh pengunjung agrowisata (batang/tahun), luas lahan yang digunakan oleh petani dalam bertanam krisan $\left(\mathrm{m}^{2}\right)$, serta banyaknya tenaga kerja yang terlibat dalam proses produksi bunga krisan (HOK).

\section{Uji Asumsi Klasik}

Berdasarkan hasil uji menggunakan aplikasi SPSS versi 16.0 diperoleh hasil nilai tolerance $\geq 0,1$ dan VIF $\leq 10,000$. Hal tersebut sesuai dengan pendapat Prasetyo (2013) yang menyatakan bahwa multikolinearitas dapat diidentifikasikan melalui nilai tolerance dan VIF, jika nilai tolerance $\geq 0,1$ dan nilai VIF $\leq 10,000$ maka dapat disimpulkan bahwa antar variabel independen tidak terjadi multikolinearitas. Data pada model regresi linier dalam penelitian ini tidak mengalami heteroskedastisitas, karena titik-titik yang ada menyebar secara merata dan tidak membentuk suatu pola tertentu. Nilai DW 
Agrisaintifika

Jurnal Ilmu-Ilmu Pertanian

Vol. 2, No. 1, 2018

Lestariningsih, et al. 2018

sebesar 1,771 , nilai tersebut lebih besar dari $\mathrm{dU}$, dan (4-DW) lebih besar dari dU, dapat juga dituliskan jika (4-DW) $>\mathrm{dU}<\mathrm{DW}=2,229$ $>1,7323<1,771$, sehingga dapat dikatakan bahwa pada model regresi linier tersebut tidak terjadi autokorelasi.

\section{Hasil Uji Regresi, Uji t, Uji F dan Uji $\mathbf{R}^{2}$}

Hasil uji regresi berkaitan dengan pengaruh agrowisata bunga krisan, yang terdiri atas variabel jumlah pengunjung yang membeli bunga, variabel jumlah bunga yang dibeli oleh pengunjung, variabel luas lahan dan variabel jumlah tenaga kerja terhadap peningkatan pendapatan petani bunga krisan di Kecamatan Bandungan Kabupaten Semarang. Uji t untuk mengetahui pengaruh secara parsial variabel-variabel independen terhadap variabel dependen, uji $\mathrm{F}$ digunakan untuk mengatahui pengaruh variabel-variabel independen secara serempak, dan uji $\mathrm{R}^{2}$ (koefisien determinasi) untuk mengetahui seberapa besar variabel agrowisata dapat menjelaskan variabel pendapatan petani.

Berdasarkan hasil uji regresi linier beganda pengaruh agrowisata terhadap peningkatan pendapatan petani menggunakan aplikasi SPSS versi 16.0 diperoleh data yang dapat dilihat pada Tabel 2.

Tabel 2. Hasil Uji t, Uji F dan Koefisien Determinasi $\left(\mathrm{R}^{2}\right)$

\begin{tabular}{|c|c|c|}
\hline Uji regresi & Unstandardized Coefficients & Uji t \\
\hline & & -sign. \\
\hline Konstanta & $2.648 .132,086$ & \\
\hline $\begin{array}{l}\mathrm{X}_{1} \text { : jumlah pengunjung yang membeli } \\
\text { bunga }\end{array}$ & $1.165 .592,100$ & 0,000 \\
\hline $\begin{array}{l}\mathrm{X}_{2}: \quad \text { jumlah bunga yang dibeli } \\
\text { pengunjung }\end{array}$ & $88.467,342$ & 0,065 \\
\hline $\mathrm{X}_{3}$ : Iuas lahan & $11.208,160$ & 0,002 \\
\hline $\mathrm{X}_{4}$ : jumlah tenaga kerja & $32.544,245$ & 0,000 \\
\hline Uji F & & 0,000 \\
\hline Koefisien Determinasi $\left(\mathrm{R}^{2}\right)$ & 0,893 & \\
\hline
\end{tabular}

Berdasarkan Tabel 2. dapat dituliskan rumus persamaan regresi dalam penelitian ini yaitu:

$Y=2.648 .132,086+1.165 .592,100 X_{1}+$ $88.467,342 X_{2}+11.208,160 X_{3}+32.544,245$ $\mathrm{X}_{4}$

Berdasarkan persamaan tersebut dapat diketahui bahwa:

a. Nilai konstanta sebesar 2.648.132,086 yang artinya jika semua variabel independen, jumlah pengunjung yang membeli bunga $\left(X_{1}\right)$, jumlah bunga yang dibeli pengunjung $\left(X_{2}\right)$, luas lahan $\left(X_{3}\right)$, jumlah tenaga kerja $\left(\mathrm{X}_{4}\right)$ bernilai 0 , maka pendapatan petani (Y) akan bernilai 2.648.132,086.

b. Nilai koefisien regresi variabel jumlah pengunjung yang membeli bunga sebesar 1.165.592,100 bernilai positif, artinya bahwa jika jumlah pengunjung yang membeli bunga meningkat 1 satuan maka akan meningkatkan pendapatan petani sebesar 1.165.592,100. Hasil uji t pada variabel jumlah pengunjung yang membeli bunga $\left(X_{1}\right)$ memiliki nilai signifikansi sebesar 0,000 , maka secara parsial jumlah pengunjung berpengaruh terhadap peningkatan pendapatan petani bunga krisan di Kecamatan Bandungan Kabupaten Semarang. Hal tersebut sesuai dengan penelitian Allifah (2014) yang menyatakan semakin banyak jumlah pembeli barang di kawasan agrowisata, maka akan semakin meningkatkan pendapatan.

c. Nilai koefisien regresi variabel jumlah bunga yang dibeli pengunjung sebesar $88.467,342$ bernilai positif, artinya bahwa jika jumlah bunga yang dibeli pengunjung meningkat 1 satuan maka akan 
meningkatkan pendapatan petani sebesar $88.467,342$. Hasil uji $t$ pada variabel jumlah bunga yang dibeli pengunjung $\left(X_{2}\right)$ memiliki nilai signifikansi sebesar 0,065, maka secara parsial jumlah bunga yang dibeli pengunjung tidak berpengaruh terhadap peningkatan pendapatan petani bunga krisan di Kecamatan Bandungan Kabupaten Semarang. Hal tersebut sesuai dengan penelitian Allifah (2014) yang menyatakan bahwa pengembangan agrowisata akan meningkatkan jumlah pengunjung, yang kemudian akan menaikkan jumlah penjualan produk oleh pedagang, hal tersebut kemudian akan meningkatkan pendapatan.

d. Nilai koefisien regresi variabel luas lahan sebesar 11.208,160 bernilai positif, artinya bahwa jika luas lahan meningkat 1 satuan maka akan meningkatkan pendapatan petani sebesar 11.208,160. Hasil uji $t$ pada variabel luas lahan $\left(X_{3}\right)$ memiliki nilai signifikansi sebesar 0,002 , maka secara parsial luas lahan berpengaruh terhadap peningkatan pendapatan petani bunga krisan di Kecamatan Bandungan Kabupaten Semarang. Hal tersebut tidak sesuai dengan penelitian Astari dan Setiawina (2016) yang menyatakan bahwa luas lahan tidak berpengaruh secara langsung maupun tidak langsung terhadap pendapatan petani asparagus di Desa Pelaga Kecamatan Petang Kabupaten Badung. Hasil penelitian ini mendukung penelitian Phahlevi (2013) yang menyatakan bahwa variabel luas lahan, harga jual padi dan jumlah produksi berpengaruh signifikan terhadap pendapatan petani padi sawah di Kota Padang panjang.

e. Nilai koefisien regresi variabel jumlah tenaga kerja sebesar $32.544,245$ bernilai positif, artinya bahwa jika jumlah tenaga kerja meningkat 1 satuan maka akan meningkatkan pendapatan petani sebesar 32.544,245. Hasil uji $t$ pada variabel jumlah tenaga kerja $\left(\mathrm{X}_{4}\right)$ memiliki nilai signifikansi sebesar 0,000 , maka secara parsial tenaga kerja berpengaruh terhadap peningkatan pendapatan petani bunga krisan di Kecamatan Bandungan Kabupaten Semarang. Hal tersebut tidak sesuai penelitian Astari dan Setiawina (2016) yang menyatakan bahwa tenaga kerja tidak berpengaruh secara langsung terhadap pendapatan petani. Tenaga kerja dimediasi oleh produksi dalam pengaruhnya terhadap pendapatan petani asparagus di Desa Pelaga Kecamatan Petang Kabupaten Badung.

Tabel 2. Menunjukkan bahwa bahwa hasil uji $F$ yang dilakukan diperoleh nilai signifikansi sebesar $0,000(<0,05), \mathrm{H}_{0}$ ditolak dan $\mathrm{H}_{a}$ diterima, sehingga dapat disimpulkan bahwa adanya agrowisata, dengan jumlah pengunjung yang membeli bunga $\left(X_{1}\right)$, jumlah bunga yang dibeli pengunjung $\left(\mathrm{X}_{2}\right)$, luas lahan $\left(X_{3}\right)$ dan jumlah tenaga kerja $\left(X_{4}\right)$ sebagai variabel independen berpengaruh secara serempak terhadap peningkatan pendapatan petani bunga krisan di Kecamatan Bandungan Kabupaten Semarang (Y). Uji F digunakan untuk menjelaskan pengaruh variabel-variabel independen terhadap variabel dependen secara serempak. Hal tersebut sesuai dengan penelitian Nurhayati et al. (2014) yang menyatakan bahwa pengembangan agrowisata mampu memberikan peningkatan terhadap pendapatan petani. Hal tersebut juga memperkuat Allifah (2014) yang menyatakan bahwa pengembangan agrowisata mampu memberikan peningkatan pendapatan rata-rata. Rata-rata pendapatan setelah berkembangnya Agrowisata Gunung Mas yaitu Rp 1.218.000 yang sebelumnya Rp 903.333. Rata-rata peningkatan pendapatan terjadi pada pedagang yang berjualan di Agrowisata Gunung Mas. Hal tersebut terjadi karena banyaknya pengunjung agrowisata akan mengakibatkan peningkatan pada jumlah pembeli dan volume penjualan oleh pedagang. 
Koefisien determinasi digunakan untuk mengetahui seberapa besar pengaruh variabel independen terhadap variabel dependen, yang dapat dilihat dari nilai Adjusted $R$ Square. Berdasarkan Tabel 2. dapat diketahui bahwa nilai Adjusted $R$ Square sebesar 0,893, hal tersebut menunjukkan bahwa variabel agrowisata (jumlah pengunjung yang membeli bunga, jumlah bunga yang dibeli pengunjung, luas lahan dan jumlah tenaga kerja) berpengaruh sebesar $89,3 \%$ terhadap peningkatan pendapatan petani, sedangkan sisanya sebesar $10,7 \%$ dipengaruhi oleh variabel lain yang tidak diajukan dalam penelitian ini.

\section{KESIMPULAN}

1. Terdapat perbedaan pendapatan petani bunga krisan sebelum dan sesudah adanya agrowisata. Pendapatan petani setelah adanya agrowisata lebih tinggi dibanding pendapatan petani sebelum adanya agrowisata.

2. Agrowisata berpengaruh terhadap peningkatan pendapatan petani bunga krisan di Kecamatan Bandungan Kabupaten Semarang yang ditunjukkan oleh hasil uji regresi berganda yang memiliki nilai signifikansi 0,000 .

\section{DAFTAR PUSTAKA}

Allifah, A.N. 2014. Dampak agrowisata terhadap pendapatan para pedagang di Agrowisata Gunung Mas PTPN VIII. Jurnal Agri Science, Vol 1 No. 4 hal : 91-99.

Astari, N.N.T. dan N.D. Setiawina. 2016. Pengaruh luas lahan, tenaga kerja dan pelatihan melalui produksi sebagai variabel intervening terhadap pendapatan petani asparagus di Desa Pelaga Kecamatan Petang Kabupaten Badung. Jurnal Ekonomi dan Bisnis Universitas Udayana, Vol 5 No. 7 hal : 2211-2230.
Blocher, E.J. 2007. Manajemen Biaya. Salemba Empat, Jakarta.

Dantes, N. 2012. Metode Penelitian. Andi Offset, Yogyakarta.

Ekowati, T., D. Sumarjono, H. Setiyawan., dan E. Prasetyo. 2014. Usahatani. Badan Penerbit Fakultas Peternakan dan Pertanian Universitas Diponegoro, Semarang.

Ekowati, T., E. Prasetyo, D. Sumarjono dan A. Setiadi. 2016. Buku Ajar Studi Kelayakan dan Evaluasi Proyek. Media Semesta Inspirasi, Semarang.

Ghozali, I. 2007. Aplikasi Analisis Multivariate dengan Program SPSS. Badan Penerbit Universitas Diponegoro, Semarang.

Kementrian Pariwisata. 2016. Laporan Akuntabilitas Kinerja Kementrian Pariwisata tahun 2016. Biro Perencanaan dan Keuangan Sekretariat Kementrian, Jakarta.

Nurhayati, A., S. Marwati dan Agustino. 2014. Peranan agrowisata terhadap peningkatan pendapatan petani stroberi di Kelurahan Kalisoro Kecamatan Tawangmangu. Jurnal Agrista, Vol 3 No. 2 hal : 1-12.

Phahlevi, R. 2013. Faktor-faktor yang Mempengaruhi Pendapatan Petani Padi Sawah di Kota Padang Panjang. Skripsi Fakultas Ekonomi. Universitas Negeri Padang, Sumatera Barat.

Prasetyo, E. 2013. Efisiensi dan Optimasi Usaha Penggemukan Ternak Sapi Potong pada Tingkat Peternak Rakyat di Jawa Tengah (Disertasi). Fakultas Peternakan dan Pertanian, Universitas Diponegoro, Semarang.

Santoso, S. 2010. Statistik Parametrik. Elex Media Komputindo, Jakarta.

Sukirno, S. 2000. Mikro Ekonomi Modern: Perkembangan Pemikiran dari Klasik sampai Keynesian Baru, Edisi 1. PT Raja Grafindo. Jakarta. 
Lestariningsih, et al. 2018

Yusri. 2016. Ilmu Pragmatik dalam Perspektif

Kesopanan Berbahasa Edisi Pertama.

Budi Utama, Yogyakarta.

Zulfikar. 2016. Pengantar Pasa Modal dengan Pendekatan Statistika. Budi Utama, Yogyakarta. 